\title{
Involution of breast tissue and mammographic density
}

\author{
Gertraud Maskarinec ${ }^{*}$ (D), Dan Ju, David Horio, Lenora W. M. Loo and Brenda Y. Hernandez
}

\begin{abstract}
Background: Mammographic density decreases and involution of breast tissue increases with age; both are thought to be risk factors for breast cancer. The current study investigated the relationship between involution or hormone treatment $(\mathrm{HT})$ and breast density among multiethnic patients with breast cancer in Hawaii.

Methods: Patients with breast cancer cases were recruited from a nested case-control study within the Multiethnic Cohort. HT use was self-reported at cohort entry and at the time of the density study. Mammographic density and involution in adjacent non-tumor breast tissue were assessed using established methods. Linear regression was applied to evaluate the correlation between involution and four density measures and to compute adjusted means by involution status while adjusting for confounders.
\end{abstract}

Results: In the 173 patients with breast cancer, mean percent breast density was $41.2 \%$ in mammograms taken approximately 1 year before diagnosis. The respective proportions of women with no, partial, and complete involution were $18.5,51.4$, and $30.1 \%$, respectively and the adjusted density values for these categories were 32.5 , 39.2 , and $40.2 \%(p=0.15)$. In contrast, the size of the dense area was significantly associated with involution $(p=0$. 001); the values ranged from $29.7 \mathrm{~cm}^{2}$ for no involution to $48.0 \mathrm{~cm}^{2}$ for complete involution. The size of the total breast area but not of the non-dense areas was also larger with progressive involution. Percent density and dense area were significantly higher in women with combined HT use.

Conclusions: Contrary to previous reports, greater lobular involution was not related to lower mammographic density but to higher dense area. Possibly, percent density during the involution process depends on the timing of mammographic density assessment, as epithelial tissue is first replaced with radiographically dense stromal tissue and only later with fat.

Keywords: Breast tissue, Marker expression, Tissue microarray, Immunohistochemistry, Ethnicity

\section{Background}

The human breast has 15-20 lobes, each with many lobules containing acini, the secretory structures of the breast [1]. Lobules are surrounded by varying amounts of stroma and fat. With age, the progressive replacement of glandular elements with collagen and fat is accompanied by histologic loss of epithelial cells available for malignant transformation and results in lobules characterized by acinar epithelia and fibrosis of the intralobular stroma $[2,3]$. Delayed involution [2], i.e., variations in the rate or extent of decrease in the number and size of breast lobules with aging contributes to breast cancer risk [4]. For example, women with only type I lobules, i.e., complete involution,

\footnotetext{
* Correspondence: gertraud@cc.hawaii.edu

University of Hawaii Cancer Center, 701 Ilalo Street, Honolulu, HI 96813, USA
}

had a lower breast cancer risk than women with type II and type III lobules $[2,5]$.

Involution of the glandular structures of the breast may be reflected in mammographic density, an independent predictor of breast cancer. Women with extensive breast density $(>75 \%)$ have fourfold to six-fold higher risk than women with low $(<5 \%)$ density [6,7]. Tissues with low and high mammographic density differ in their proportion of stroma, collagen, epithelium, and fat [8], but dense areas represent epithelial and stromal tissues [9]. Biological processes underlying breast involution and density may share common hormonal influences, such as hormone therapy (HT), which affects breast cancer risk, involution, and mammographic density $[10,11]$. 
In women attending the Mayo clinic with benign breast disease, the mean percent density values by none, partial, and complete involution status were 22,22 , and $17 \%$, respectively, after adjustment for known risk factors [1]. In a case-control study within the same population [6], the combination of no involution plus dense breasts was related to fourfold higher risk of breast cancer. A later report on women with benign biopsies also described a significant inverse association between involution and percent density but not absolute density, particularly among premenopausal women [12]. In the current study, we analyzed the association between breast density and involution as the primary objective, but also examined the well-known association between HT and mammographic density among women in Hawaii.

\section{Methods}

\section{Study population}

The current pathologic investigation [13] is based on Hawaii participants of the Multiethnic Cohort (MEC), who took part in a nested case-control (NCC) study of mammographic density and breast cancer risk [14]. The MEC was established in 1993-1996 by mailing a selfadministered, 26-page questionnaire asking about demographic, anthropometric, and medical factors to men and women ages 45-75 years residing in Hawaii and California [15]. Additional information on HT, menopausal status, and mammograms was obtained when women enrolled in the NCC study.

The MEC is linked annually to the statewide Hawaii Tumor Registry (HTR) to identify incident cancer cases. Invitations for the pathology study were mailed to 430 of the 607 women in the NCC study, for whom tumor blocks were available through the HTR. Of the 279 women with breast tumor tissue represented on microarrays [16], blocks with sufficient non-tumor tissue to assess breast involution were only available for 173 women, as many of the biopsy specimens were small and did not contain enough benign tissue to evaluate involution. The Institutional Review Board at the University of Hawaii approved all study protocols; all women signed informed consent to be part of the NCC and the pathology investigation.

\section{Mammographic density assessment}

Mammographic images of study participants from clinics throughout the State of Hawaii were retrieved and digitized using a Kodak LS 85 Film Digitizer (Kodak, Rochester, NY, USA) with a pixel size of $260 \mu \mathrm{m}$ [14]. For the pathology study, the results of craniocaudal-projection images obtained closest to, but before, the date of diagnosis were selected [13]. Using the Cumulus software developed at the University of Toronto, Canada [17], the scanned images for both breasts were assessed for density (Fig. 1) by one reader
(GM) who was blinded to case status and time sequence of mammograms [14]. Percent density was computed as the dense area divided by the total breast area and non-dense area as the difference between the total breast and the dense area. The intraclass correlation coefficients derived from duplicate readings were 0.96 for the size of the dense area and 0.97 for percent density [14].

\section{Pathologic assessment of lobular involution}

Pathologic blocks were retrieved through the tissue repository of the HTR. H\&E slides (mean $=2.6$ per woman) of normal (non-tumor) tissue adjacent to but not immediately bordering the tumor were prepared. The extent of breast tissue lobular involution (Fig. 1) in breast tissue was evaluated by a pathologist $(\mathrm{DH})$ who was blinded to mammographic, clinical, and risk factor data. The extent of lobular involution was based on morphologic assessment of terminal duct lobular units (TDLUs) classified into one of three categories [18]: no involution ( $0 \%$ involuted), partial $(1-74 \%)$, or complete $(\geq 75 \%)$. TDLUs with abnormal features (e.g. dilation of acini, hyperplasia, metaplasia, or calcifications) were excluded from evaluation.

\section{Statistical analysis}

The statistical analysis was performed using the SAS statistical software (SAS Institute Inc., Cary, NC, USA). We computed frequencies and means for variables of interest by involution status. Multiple linear regression was applied to evaluate the relationship between involution and mammographic measures (percent density, dense area, non-dense area, and total area) and to compute adjusted means by the category of involution and HT. Separate models for premenopausal and postmenopausal women were analyzed. Trend tests were performed using the indicator variables for involution status as a continuous variable. All models were adjusted for covariates known to be associated with breast density: age at mammogram, body mass index (BMI) $\left(<25,25\right.$ to $\left.<30, \geq 30 \mathrm{~kg} / \mathrm{m}^{2}\right)$, ethnicity (Caucasian, Native Hawaiian, Japanese, other), parity (0, 1-2, 3+), menopausal status, and HT use (none, estrogen only, estrogen plus progesterone).

\section{Results}

The mean age at breast cancer diagnosis in the 173 women in the involution study (62\% of the original study population) was $59.7 \pm 8.0$ years as compared to $61.4 \pm$ 8.7 years in the 279 participants in the original study (Table 1). The distributions of ethnicity, BMI, and reproductive factors, HT use, and cancer stage) were very similar in the subset and the original study, but percent density and dense area were slightly higher and nondense and total area lower than in the entire study 


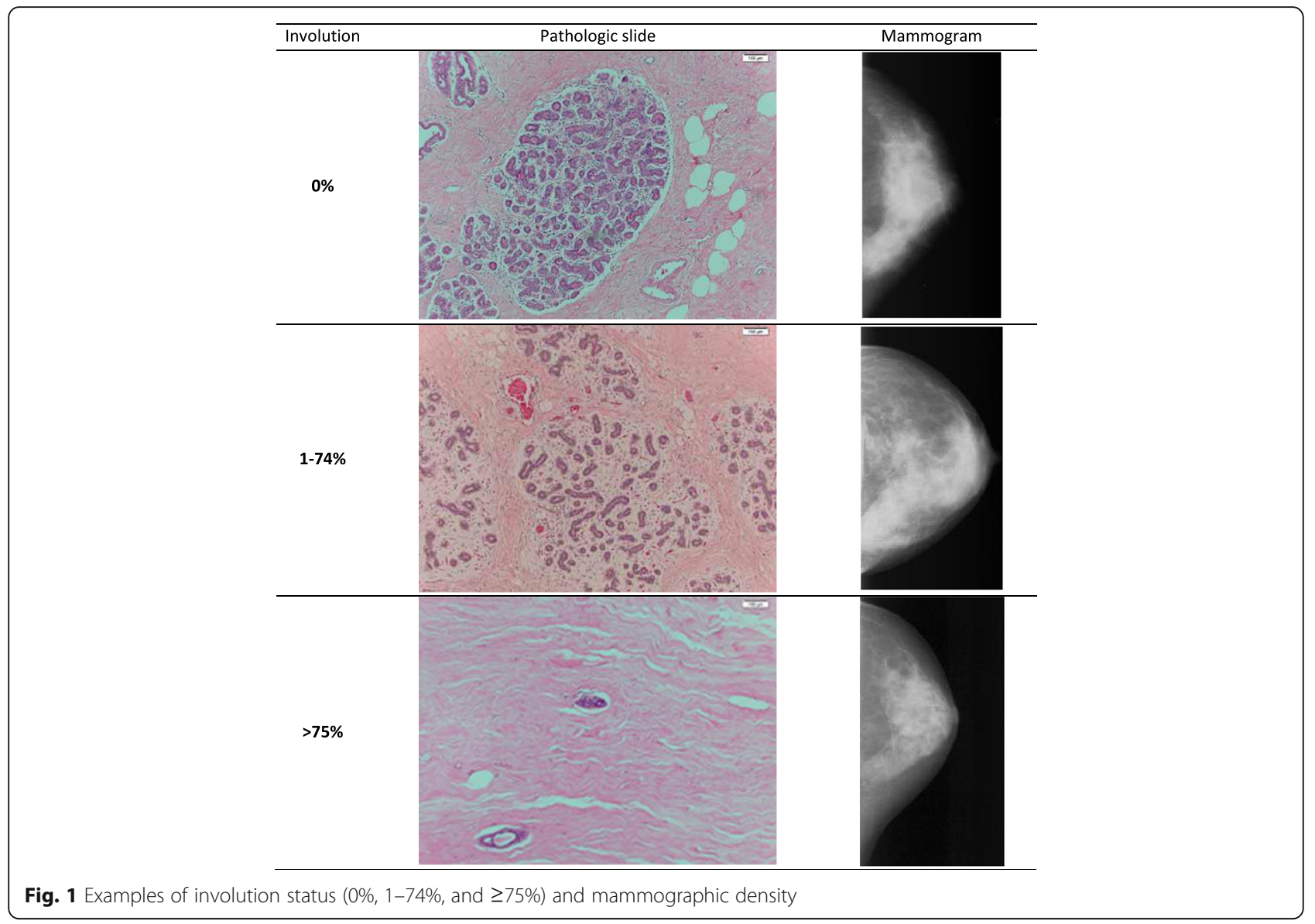

population, in mammograms taken $1.1 \pm 1.1$ years before diagnosis. Approximately half of the women (51.4\%) were classified as having partial involution, followed by $30.1 \%$ and $18.5 \%$ with complete and no involution, respectively. The majority of women were postmenopausal (69.4\%). The population represented Caucasians (33.5\%), Japanese (46.2\%), Native Hawaiians (11.0\%), and other ethnic groups (9.3\%). Past or present HT use was reported by $65.9 \%$ of all women. The cancer stage in the majority of women was localized (60.7\%), followed by in situ (22.5\%) and advanced (12.1\%). Involution status differed significantly by age at diagnosis $(p=0.01)$ with low involution among women under 50 years of age and higher proportions in women 60 years and older (Table 1). Partial and complete involution did not differ significantly by previous HT $(p=0.58)$.

The mean breast density in all women was $41.2 \%$; the unadjusted values (Fig. 2) were similar for no, partial, and complete involution $(38.8,42.8$, and $40.0 \%$, respectively; $p=0.96$ ). The difference across categories increased after adjustment for confounders (32.5, 39.2, and $40.2 \%$, respectively) but was not significant $(p=0.15)$. In contrast, the size of the dense area differed significantly in the unadjusted $(p=0.03)$ and adjusted models $(p=0.001)$ with the highest value for women with complete involution $\left(48.0 \mathrm{~cm}^{2}\right)$ and the lowest $\left(29.7 \mathrm{~cm}^{2}\right)$ for those with no involution. The non-dense area varied little $(80.9,77.5$, and $83.4 \mathrm{~cm}^{2}$, respectively; $p=0.72$ ), whereas the total breast area was significantly higher with more advanced involution before $(p=0.009)$ and after adjustment (110.6, $118.4,131.4 \mathrm{~cm}^{2}$, respectively, $p=0.02$ ). Interaction terms and stratified analyses did not indicate any differences by menopausal status. Involution was not associated with percent density in premenopausal or postmenopausal women ( $p=0.27$ and 0.42 , respectively), whereas the dense area remained higher with progressive involution ( $p=0.04$ and 0.02 , respectively).

HT was significantly associated with several mammographic measures (Fig. 2). Percent density (30.7, 36.5, and 44.6\%; $p=0.01)$ and dense area $\left(31.2,37.7,49.7 \mathrm{~cm}^{2}\right.$; $p=0.002)$ were higher in women with combined HT use, but the non-dense and the total area was not associated with HT use.

\section{Discussion}

As in previous reports, age was a strong predictor of involution among MEC participants in Hawaii; complete involution is uncommon before the age of 50 years and 
Table 1 Characteristics of 173 study participants with breast cancer in the Multiethnic Cohort

\begin{tabular}{|c|c|c|c|c|c|c|}
\hline Characteristic $^{a}$ & $\begin{array}{l}\text { Original } \\
\text { study }\end{array}$ & $\begin{array}{l}\text { Involution } \\
\text { study }\end{array}$ & $\begin{array}{l}\text { No involution } \\
(0 \%)\end{array}$ & $\begin{array}{l}\text { Partial involution } \\
(1-74 \%)\end{array}$ & $\begin{array}{l}\text { Complete involution } \\
(\geq 75 \%)\end{array}$ & $P$ value $^{\mathrm{b}}$ \\
\hline Sample size (\%) & 279 & 173 & $32(18.5)$ & $89(51.4)$ & $52(30.1)$ & N/A \\
\hline \multicolumn{7}{|l|}{ Age at diagnosis } \\
\hline$<50$ years & $24(8.6)$ & $15(8.7)$ & $7(21.9)$ & $7(7.9)$ & $1(1.9)$ & \multirow[t]{5}{*}{0.01} \\
\hline 50 to $<55$ years & $56(20.1)$ & $42(24.3)$ & $6(18.8)$ & $25(28.1)$ & $11(21.2)$ & \\
\hline 55 to $<60$ years & $55(19.7)$ & $40(23.1)$ & $12(37.5)$ & $18(20.2)$ & $10(19.2)$ & \\
\hline 60 to $<65$ years & $44(14.3)$ & $31(17.9)$ & $3(9.4)$ & $17(19.1)$ & $11(21.2)$ & \\
\hline $65+$ years & $104(37.3)$ & $45(26.0)$ & $4(12.5)$ & $22(24.7)$ & $19(36.5)$ & \\
\hline \multicolumn{7}{|l|}{ Menopausal status (\%) } \\
\hline Premenopausal & $76(27.2)$ & 53 (30.6) & $12(37.5)$ & $28(31.5)$ & $13(25.0)$ & \multirow[t]{2}{*}{0.47} \\
\hline Postmenopausal & $203(72.8)$ & $120(69.4)$ & $20(62.5)$ & $61(68.5)$ & $39(75.0)$ & \\
\hline \multicolumn{7}{|l|}{ Ethnicity (\%) } \\
\hline Caucasian & $97(34.8)$ & $58(33.5)$ & $7(21.9)$ & $35(39.3)$ & $16(30.8)$ & \multirow[t]{4}{*}{0.39} \\
\hline Japanese American & $121(43.4)$ & $80(46.2)$ & $16(50.0)$ & $39(43.8)$ & $25(48.1)$ & \\
\hline Native Hawaiian & $36(12.9)$ & $19(11.0)$ & $6(18.8)$ & $6(6.7)$ & $7(13.5)$ & \\
\hline Other & $25(8.9)$ & $16(9.3)$ & $3(9.4)$ & $9(7.7)$ & $4(7.7)$ & \\
\hline \multicolumn{7}{|l|}{ Parity } \\
\hline Nulliparous & $47(16.9)$ & $25(14.4)$ & $6(18.8)$ & $8(9.0)$ & $11(21.2)$ & \multirow[t]{3}{*}{0.16} \\
\hline $1-2$ children & $110(39.4)$ & 69 (39.9) & 15(46.9) & $38(42.7)$ & $16(30.8)$ & \\
\hline 3 or more children & $122(43.7)$ & $79(45.7)$ & $11(34.4)$ & $43(48.3)$ & $25(46.1)$ & \\
\hline \multicolumn{7}{|l|}{ Hormone use (\%) } \\
\hline Never & $102(36.5)$ & $59(34.1)$ & $9(28.1)$ & $28(31.5)$ & $22(42.3)$ & \multirow[t]{3}{*}{0.58} \\
\hline Estrogen & $97(34.8)$ & $62(35.8)$ & $11(34.4)$ & $34(38.2)$ & $17(32.7)$ & \\
\hline Estrogen/progesterone & $80(28.7)$ & $52(30.1)$ & $12(37.5)$ & $27(30.3)$ & $13(25.0)$ & \\
\hline \multicolumn{7}{|l|}{ Body mass index } \\
\hline$<25 \mathrm{~kg} / \mathrm{m}^{2}$ & $167(59.9)$ & $104(60.1)$ & $18(56.3)$ & $56(62.9)$ & $30(57.7)$ & \multirow[t]{3}{*}{0.60} \\
\hline 25 to $<30 \mathrm{~kg} / \mathrm{m}^{2}$ & $81(29.0)$ & $54(31.2)$ & $12(37.5)$ & $27(30.3)$ & $17(28.9)$ & \\
\hline $30+\mathrm{kg} / \mathrm{m}^{2}$ & $31(11.1)$ & $15(8.7)$ & $2(6.3)$ & $6(6.7)$ & $7(13.5)$ & \\
\hline \multicolumn{7}{|l|}{ Tumor stage (\%) } \\
\hline In situ & $61(21.9)$ & $39(22.6)$ & $10(31.3)$ & $18(20.2)$ & $11(21.2)$ & \multirow[t]{4}{*}{0.60} \\
\hline Localized & $169(60.6)$ & $105(60.7)$ & $20(62.5)$ & $53(59.6)$ & $32(61.5)$ & \\
\hline Advanced & $37(13.2)$ & $21(12.1)$ & $2(6.3)$ & $13(14.6)$ & $6(11.5)$ & \\
\hline Missing & $12(4.3)$ & $8(4.6)$ & $0(0.0)$ & $5(5.6)$ & $3(5.8)$ & \\
\hline \multicolumn{7}{|l|}{ Mammographic measures } \\
\hline Percent density & 37.6 & 41.2 & 38.8 & 42.8 & 40.0 & 0.96 \\
\hline Dense area $\left(\mathrm{cm}^{2}\right)$ & 37.8 & 40.8 & 32.6 & 41.6 & 44.7 & 0.04 \\
\hline Non-dense area $\left(\mathrm{cm}^{2}\right)$ & 77.5 & 67.8 & 63.9 & 64.9 & 75.1 & 0.24 \\
\hline Total area $\left(\mathrm{cm}^{2}\right)$ & 115.3 & 108.6 & 96.5 & 106.4 & 119.5 & 0.02 \\
\hline
\end{tabular}

a Numbers and percentages except for mammographic measures; percentages may not add up to 100 due to rounding

${ }^{\mathrm{b}}$ Based on the chi-square test for categorical variables and general linear models for continuous variables

increases to as much as $50 \%$ in women aged 60 years and older [2,9]. In the current analysis, women with more advanced involution had greater dense and total breast areas, whereas percent density and non-dense area were not related to involution. This lack of an association between involution and percent density is in contrast to a Mayo study, in which there was lower percent density with more advanced involution [1], and an investigation of benign diagnostic biopsies reporting a direct association between percent mammographic 


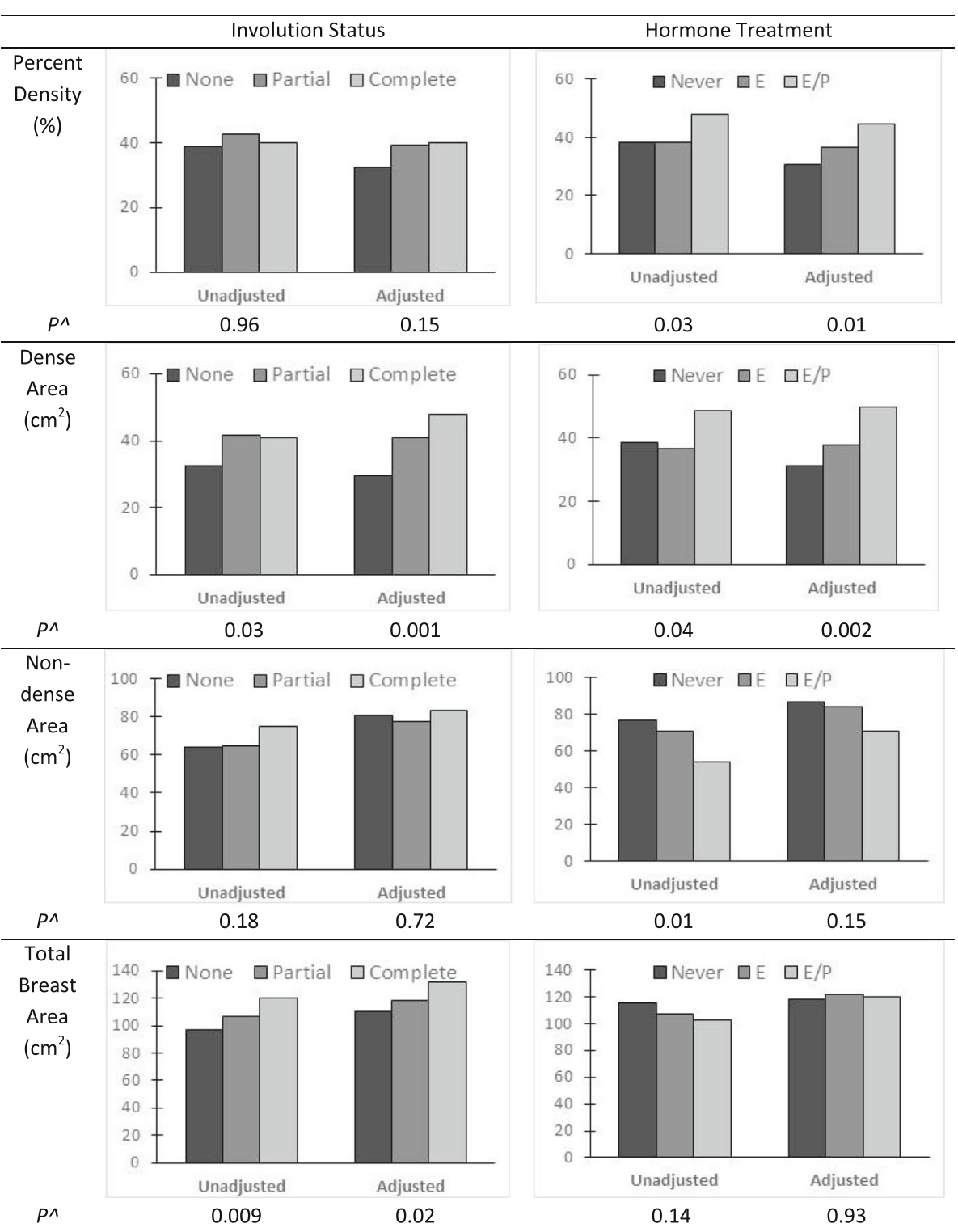

Fig. 2 Mammographic measure by involution status and hormone treatment. Means and $p$ values were obtained using general linear models and were adjusted for ethnicity, age, body mass index, menopausal status, and parity. $E$ estrogen, $P$ progesterone

density and TDLU count around the biopsy site, but primarily in premenopausal women [12]. There was no association between involution and absolute dense area/ volume in either of these reports. Unlike in the study by Gierach et al. [12], the associations in the current analysis did not differ by menopausal status. In a study from Vermont that examined the relationship between circulating IGF-1 and involution or breast density, the positive correlation between TDLU counts and percent density was not significant after adjustment for confounders [19].

Our finding of larger dense areas on mammograms of more involuted breasts suggests that women with a larger degree of involution may not have more fatty tissue but rather a higher proportion of stromal tissue. Thus, the mammographic images appear radiographically dense despite being poor in epithelial cells. In the two previous reports $[1,12]$ of inverse associations between involution and percent density, but not with dense area, the authors argued that lobules were not replaced exclusively by stroma but by a combination of stroma and fat [1]. Possible reasons for the discrepant results include the small sample size of 173 women, the ethnic diversity, and the fact that all women were diagnosed with breast cancer. As the pathology specimens were obtained from the area surrounding the tumor in 
previous studies, they likely represented higher-risk tissue than breast tissue identified as benign on biopsy obtained prior to cancer diagnosis $[1,12]$.

Our findings confirm the strong association between mammographic density and HT, especially estrogen and progesterone combined [20], but the degree of involution was only weakly associated with HT in the current analysis, although previous reports describe less involution in women taking HT and suggest that estrogens play a role in involution and breast density [1]. It has also been reported that postmenopausal women with higher estradiol levels were more likely to have higher TDLU counts [21]. While exogenous intake of estrogen may stimulate growth in breast tissue and provide more epithelial cells at risk of mutation, estrogen could also delay the age-related involution of the lobules through mechanisms that are yet to be defined [4]. The importance of breast tissue structure was emphasized by a case-control study within the Nurses' Health study [5]; women with predominant type I and no type III lobules had a 30\% lower risk of breast cancer than those with no type I lobules or mixed lobule types.

Strengths of the current study include the ethnic diversity with a wide range of mammographic density values [14], the availability of many covariates, and the quantitative breast density assessment providing dense and non-dense area measures. However, the major weakness is that all participants of the current study were diagnosed with breast cancer, thus, their breast tissue may have been less involuted than tissue in women with benign biopsies $[1,12]$ and may be responsible for the observed positive associations. Other limitations include the lack of slides for more than 100 women who participated in the original study [16]. Although the distribution by stage of diagnosis for the current study samples was similar to the original 279 study participants (Table 1), the study population was slightly younger and the total breast area was larger and the dense area smaller, resulting in lower percent density (Table 1). As different approaches in assessing involution have been applied, i.e., TDLU counts, TDLU span, and acini counts/TDLU, it is not clear how comparable our findings, based on a simple method, are to previous reports. Nevertheless, all measures started declining significantly in the third decade of age and all metrics were statistically significantly lower among postmenopausal women [18].

\section{Conclusions}

Contrary to previous reports $[1,12]$, greater lobular involution was not related to lower mammographic density but to higher dense area, in the current analysis of a small number of breast cancer cases. It is possible that percent density during the involution process depends on the timing of mammographic density assessment, as epithelial tissue is first replaced with radiographically dense stromal tissue and only later with fat. Hence, percent density in breast tissue undergoing involution may depend on the timing within the involution process when mammographic density was assessed. In addition to epithelial cell death and remodeling, the presence of immune cells and inflammatory response to remove debris may influence the appearance of the breast $[3,22]$. Based on the limited evidence, it is tempting to consider involution and mammographic density as intermediate endpoints in breast carcinogenesis [6], as both measures are related to aging, as collagen, glandular area, and nuclear area [10], and rely on visual assessments of tissue architecture, one at the microscopic and the other at the macroscopic level. However, at this time we do not have information on the average rate of involution, the timing of the transitional process, and possible differences in the process among women with and without breast cancer.

\section{Abbreviations}

BMI: body mass index; H\&E: hematoxylin and eosin; HT: hormone use; HTR: Hawaii Tumor Registry; MEC: multiethnic cohort; NCC: nested casecontrol study; TDLU: terminal duct lobular unit

\section{Acknowledgements \\ We are grateful to the study participants and the staff of the Hawaii Tumor Registry. \\ Funding \\ The involution work was supported by a pilot grant from the University of Hawaii Foundation. The breast pathology study and the case-control study were funded the National Cancer Institute (R21 CA1080250 and R01 CA85265). The Hawaii Tumor Registry is supported by NCl contract N01-PC- 35137.}

\section{Availability of data and materials}

The datasets used during the current study are available from the corresponding author on reasonable request.

\section{Authors' contributions}

GM, LWML, and BYH conceived and designed the study and collected participant data. GM performed the mammographic density assessment. DH evaluated and interpreted the involution status of the tissue samples. GM and DJ performed statistical analysis and all co-authors interpreted the data. DJ and GM drafted the manuscript. All authors contributed with critical revision, approved the final version for publication, and agreed to be accountable for the accuracy and integrity of the work.

\section{Authors' information}

None provided.

\section{Competing interests}

The authors declare that they have no competing interests.

Consent for publication

Not applicable.

Ethics approval and consent to participate

All participants provided written informed consent, and the study was approved by the Institutional Review Board at the University of Hawaii.

Received: 23 September 2016 Accepted: 2 December 2016

Published online: 15 December 2016 


\section{References}

1. Ghosh K, Hartmann LC, Reynolds C, Visscher DW, Brandt KR, Vierkant RA Scott CG, Radisky DC, Sellers TA, Pankratz VS, et al. Association between mammographic density and age-related lobular involution of the breast. $J$ Clin Oncol. 2010;28:2207-12.

2. Milanese TR, Hartmann LC, Sellers TA, Frost MH, Vierkant RA, Maloney SD, Pankratz VS, Degnim AC, Vachon CM, Reynolds CA, et al. Agerelated lobular involution and risk of breast cancer. J Natl Cancer Inst. 2006;98:1600-7.

3. Watson CJ, Kreuzaler PA. Remodeling mechanisms of the mammary gland during involution. Int J Dev Biol. 2011;55:757-62.

4. Henson DE, Tarone RE. Involution and the etiology of breast cancer. Cancer. 1994;74:424-9.

5. Baer HJ, Collins LC, Connolly JL, Colditz GA, Schnitt SJ, Tamimi RM. Lobule type and subsequent breast cancer risk: results from the Nurses' Health Studies. Cancer. 2009;115:1404-11.

6. Ghosh K, Vachon CM, Pankratz VS, Vierkant RA, Anderson SS, Brandt KR, Visscher DW, Reynolds C, Frost MH, Hartmann LC. Independent association of lobular involution and mammographic breast density with breast cancer risk. J Natl Cancer Inst. 2010;102:1716-23.

7. McCormack VA, dos Santos Silva I. Breast density and parenchymal patterns as markers of breast cancer risk: a meta-analysis. Cancer Epidemiol Biomarkers Prev. 2006:15:1159-69.

8. Huo CW, Chew G, Hill P, Huang D, Ingman W, Hodson L, Brown KA,

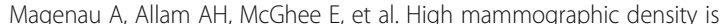
associated with an increase in stromal collagen and immune cells within the mammary epithelium. Breast Cancer Res. 2015;17:79.

9. Ghosh K, Brandt KR, Reynolds C, Scott CG, Pankratz VS, Riehle DL, Lingle WL, Odogwu T, Radisky DC, Visscher DW, et al. Tissue composition of mammographically dense and non-dense breast tissue. Breast Cancer Res Treat. 2012;131:267-75.

10. Ginsburg OM, Martin LJ, Boyd NF. Mammographic density, lobular involution, and risk of breast cancer. Br J Cancer. 2008;99:1369-74.

11. Boyd NF, Martin LJ, Li Q, Sun L, Chiarelli AM, Hislop G, Yaffe MJ, Minkin S. Mammographic density as a surrogate marker for the effects of hormone therapy on risk of breast cancer. Cancer Epidemiol Biomarkers Prev. 2006;15:961-6.

12. Gierach GL, Patel DA, Pfeiffer RM, Figueroa JD, Linville L, Papathomas D, Johnson JM, Chicoine RE, Herschorn SD, Shepherd JA, et al. Relationship of terminal duct lobular unit involution of the breast with area and volume mammographic densities. Cancer Prev Res (Phila). 2016;9:149-58.

13. Verheus M, Maskarinec G, Erber E, Steude JS, Killeen J, Hernandez BY, Cline JM. Mammographic density and epithelial histopathologic markers. BMC Cancer. 2009;9:182.

14. Maskarinec G, Pagano I, Lurie G, Wilkens LR, Kolonel LN. Mammographic density and breast cancer risk: the multiethnic cohort study. Am J Epidemiol. 2005;162:743-52.

15. Kolonel LN, Henderson BE, Hankin JH, Nomura AMY, Wilkens LR, Pike MC, Stram DO, Monroe KR, Earle ME, Nagamine FS. A multiethnic cohort in Hawaii and Los Angeles: baseline characteristics. Am J Epidemiol. 2000; 151:346-57

16. Maskarinec G, Erber E, Verheus M, Hernandez BY, Killeen J, Cashin S, Cline JM. Soy consumption and histopathologic markers in breast tissue using tissue microarrays. Nutr Cancer. 2009;61:708-16.

17. Byng JW, Boyd NF, Fishell E, Jong RA, Yaffe MJ. The quantitative analysis of mammographic densities. Phys Med Biol. 1994:39:1629-38.

18. Figueroa JD, Pfeiffer RM, Patel DA, Linville L, Brinton LA, Gierach GL, Yang XR, Papathomas D, Visscher D, Mies C et al. Terminal duct lobular unit involution of the normal breast: implications for breast cancer etiology. $J$ Natl Cancer Inst. 2014;106(10). doi:10.1093/jnci/dju286.

19. Horne HN, Sherman ME, Pfeiffer RM, Figueroa JD, Khodr ZG, Falk RT, Pollak M, Patel DA, Palakal MM, Linville L, et al. Circulating insulin-like growth factor-I, insulin-like growth factor binding protein-3 and terminal duct lobular unit involution of the breast: a cross-sectional study of women with benign breast disease. Breast Cancer Res. 2016; $18: 24$

20. Greendale GA, Reboussin BA, Slone S, Wasilauskas C, Pike MC, Ursin G Postmenopausal hormone therapy and change in mammographic density. J Natl Cancer Inst. 2003:95:30-7.
21. Khodr ZG, Sherman ME, Pfeiffer RM, Gierach GL, Brinton LA, Falk RT, Patel DA, Linville LM, Papathomas D, Clare SE, et al. Circulating sex hormones and terminal duct lobular unit involution of the normal breast. Cancer Epidemiol Biomarkers Prev. 2014;23:2765-73.

22. Radisky DC, Hartmann LC. Mammary involution and breast cancer risk: transgenic models and clinical studies. J Mammary Gland Biol Neoplasia. 2009:14:181-91.

\section{Submit your next manuscript to BioMed Central and we will help you at every step:}

- We accept pre-submission inquiries

- Our selector tool helps you to find the most relevant journal

- We provide round the clock customer support

- Convenient online submission

- Thorough peer review

- Inclusion in PubMed and all major indexing services

- Maximum visibility for your research

Submit your manuscript at www.biomedcentral.com/submit 